\title{
The impact of the COVID-19 pandemic on mental health: early quarantine-related anxiety and its correlates among Jordanians
}

Islam Massad, ${ }^{1}$ Raed Al-Taher, ${ }^{2}$ Faysal Massad, ${ }^{3}$ Mohammed Qussay Al-Sabbagh, ${ }^{3}$ Murad Haddad ${ }^{3}$ and Mohammad Abufaraj ${ }^{4,5}$

${ }^{1}$ Department of Anesthesia and Intensive Care, School of Medicine, University of Jordan, Amman, Jordan. ${ }^{2}$ Division of Pediatrics Surgery, Department of General Surgery, Jordan University Hospital, University of Jordan, Amman, Jordan. ${ }^{3}$ School of Medicine, University of Jordan, Amman, Jordan. ${ }^{4}$ Division of Urology, Department of Special Surgery, Jordan University Hospital, University of Jordan, Amman, Jordan. ${ }^{5}$ Department of Urology, the Medical University of Vienna, Vienna, Austria. (Correspondence to: Islam Massad: I_massad@ju.edu.jo).

\begin{abstract}
Background: Jordan implemented a nationwide lockdown and recommended self-quarantine in response to the COVID-19 pandemic. Such measures are expected to have consequences on mental health.
\end{abstract}

Aims: In this study, we aimed to estimate the prevalence of quarantine-related anxiety and its socioeconomic correlates. Methods: An online questionnaire was utilized to collect information about quarantine-related anxiety and related factors from a non-representative sample of Jordanian population in March 2020. The Beck Anxiety Inventory (BAI) was used to ascertain the level of stress. Using STATA 16, multivariable ordinal logistic regression was done to estimate beta-coefficient $(\beta)$ and corresponding $95 \% \mathrm{CI}$ of the anxiety level.

Results: Overall, 5274 participants returned the survey. The prevalence of mild, moderate, and severe anxiety was $21.5 \%$, $10.9 \%$, and $6 \%$, respectively. Female gender $(\beta=0.47,95 \% \mathrm{CI}$ : 0.34 to 0.59 ) and more members of the household ( $\beta=0.04,95 \%$ CI: 0.00 to 0.07 ) were correlated with a higher degree of anxiety, while older age ( $\beta=-0.27,95 \%$ CI: -0.33 to -0.20$)$, having larger social network ( $\beta=-0.17,95 \%$ CI -0.22 to -0.13 ), social support $(\beta=-0.28,95 \%$ CI: -0.32 to -0.23 ), and higher income (>2000 Jordanian Dinars vs reference, $\beta=-0.52$, $95 \%$ CI: -0.71 to -0.33 ) were correlated with lower BAI scores.

Conclusion: Our findings showed that approximately four out of every ten participants experienced quarantine-related anxiety. Younger participants, women, and people with poor social support were more likely to experience quarantine-related anxiety. These findings highlight the importance of targeting these groups to mitigate the consequence of home quarantine on public health.

Keywords: mental health, stress, anxiety, COVID-19, quarantine

Citation: Massad I; Al-Taher R; Massad F; Al-Sabbagh MQ; Haddad M; Abufaraj M. The impact of the COVID-19 pandemic on mental health: early quarantine-related anxiety and its correlates among Jordanians. East Mediterr Health J. 2020;26(10):1165-1172. https://doi.org/10.26719/emhj.20.115

Received: 04/07/20; accepted: 18/08/20

Copyright (c) World Health Organization (WHO) 2020. Open Access. Some rights reserved. This work is available under the CC BY-NC-SA 3.0 IGO

license (https://creativecommons.org/licenses/by-nc-sa/3.o/igo).

\section{Introduction}

An outbreak of viral pneumonia was reported in December 2019 in Wuhan City, Hubei Province, China. A few days later, the etiology of this outbreak was identified to be a novel coronavirus that was named Severe Acute Respiratory Syndrome Coronavirus 2 (SARS-CoV2), which causes a clinical entity called coronavirus disease 2019 (COVID-19) (1). On 11 March 2020, the World Health Organization (WHO) declared COVID-19 as a global pandemic (2). Due to the lack of effective therapy for this infection (3), physical distancing, particularly self-isolation and home quarantine, are currently the most effective preventive measures (4).

Several countries witnessed an exponential growth of confirmed cases and therefore implemented home quarantine (5). On 2 March 2020, Jordan reported its first case of COVID-19. As a result, the Jordanian government undertook various measures to prevent further spread of the disease. These measures included closure of all universities and schools, suspending activities of institutions in both the public and private sectors, and executing the national defense law imposing an obligatory mass quarantine (6).

Data from previous outbreaks showed that pandemics carry serious, yet under-recognized, psychological burden. A study that investigated psychological impact of the 2013-2016 Ebola outbreak showed a wide spectrum of psychosocial consequences on individual, community and international levels (7). Infected individuals tend to be stressed due to fear of death and witnessing death of others. Even in those who survived, social and personal stigma as well as feeling of guilt and shame were common. On the community level, fear of contracting the infection and the resulting disruption to the healthcare system can adversely affect the social structure and personal interactions (7). This was also evident in the influenza A HiN1 (swine flu) outbreak, where 10-30\% of the general population in the United Kingdom were worried about contracting the infection (8).

Home quarantine is an unpleasant experience for the vast majority of people since it includes separation from family and friends, feeling of boredom and insecurity, and uncertainty over disease status and the future. These 
consequences can affect mental health and lead to acute stress disorder, anxiety or depression (9). A previous study during the SARS 2002-2004 epidemic on people living in home quarantine in Toronto, Canada, showed that almost one third of the participants had experienced symptoms of post-traumatic stress disorder (PTSD) and depression (10). Although the conditions of people living mass quarantine today could be similar to those of some previous epidemics such as SARS and Ebola, it is worth mentioning that the present massive home quarantine is the largest of its kind than any other previous epidemic, making this experience exceptional and unprecedented. Thus, addressing the consequences of these measures on mental health is of paramount importance. This study aimed to assess the prevalence of quarantine-related psychological distress and to explore sociodemographic correlates.

\section{Methods}

\section{Study setting}

Jordan is an upper middle-income country (11) with a population of 10.6 million (12). In 2019, the average gross domestic product (GDP) per capita was US\$ 4330 (11). The Jordanian populace is unevenly distributed geographically with almost two-thirds (62\%) living in the centre of the country (13). According to internet world stats (IWS), there were 8700000 internet users in December 2017. Facebook was by far the most popular website with more than $53.5 \%$ of the Jordanian population having Facebook accounts (14).

\section{Study design and sampling}

This cross-sectional study utilized an internet-based survey (using google forms), which was distributed through Facebook and Twitter pages, groups, and profiles during 23-30 March 2020 (after the execution of the national defense order). Participants were included if they were aged 18 years or older, had given consent, lived in Jordan, and use/speak Arabic as their native language. After filling in the survey, participants were encouraged to share it with their contacts to participate, resulting in a snowball sampling technique. A total of 5274 respondents agreed to participate in the study.

\section{Measurement instrument}

The study instrument was developed in the light of the literature to measure anxiety levels and associated sociodemographic factors. The included sociodemographic variables were: age (by years), sex, marital status, number of household members, social network (how many close people do you have?) and social support (how many people do you have to talk with when you are under stress?), monthly income (Jordanian Dinar), region of residence (northern regions: Irbid, Mafraq, Ajloun and Jerash; central regions: Amman, Zarqa, Madaba and Balqa; southern regions: Karak, Tafileh, Maan and Aqaba), work sector, and smoking status (if currently smoking tobacco, hookah, or E-cigarettes).
The Beck Anxiety Inventory (BAI) was used to measure anxiety levels because of its competency, validity, and reliability (Cronbach's alpha $=0.94$ ) in screening and diagnosing anxiety disorders (15). BAI is composed of 21 self-reported questions (four-point scale) describing anxiety symptoms during the last week. The total score range from 0 to 63 , anxiety levels are then stratified into minimal (0-7), mild (8-15), moderate (16-25), and severe (26-63) to aid in reporting the prevalence of anxiety and data analysis (16). Minimal anxiety was considered as the baseline stratum in comparison to those who scored mild, moderate or severe anxiety on BAI. The Arabic version of BAI has been validated and studied in Kuwait, with Cronbach's alpha values ranging from 0.83 to 0.90 (17). The whole questionnaire was translated from English to Arabic and then reverse-translated by two separate bilingual investigators. A pilot study was conducted on 100 participants, not included in this study, with Cronbach's alpha of 0.93 for BAI.

\section{Data analysis}

We analyzed the data using STATA (Stata Statistical Software: Release 16. College Station, TX: StataCorp LLC; USA). The associations between demographic variables and the BAI scale were evaluated using the Kruskal-Wallis test with statistically significant results defined as $P$-value $<0.05$. A logistic regression analysis was used to assess the association between sociodemographic factors and the degree of quarantine related anxiety. Variables were first evaluated using univariate ordinal logistic regression analysis. Then, significant variables were fitted into the final multivariable ordinal logistic regression model.

\section{Ethical considerations}

Ethical approval for this study was granted from the Medical Research Ethical Committee at the University of Jordan; all participants were informed about the nature of the study. The data were collected, coded and analyzed, and the survey was designed to provide data from anonymous individuals. The authors assert that all procedures contributing to this work comply with the ethical standards of the relevant national and institutional committees on human experimentation and with the Helsinki Declaration of 1975, as revised in 2008.

\section{Results}

\section{Characteristics of the sample}

Table 1 shows the baseline sociodemographic characteristics of the study according to BAI scores. The majority of participants were aged between 18-24 years, women $(55.3 \%)$, working in the public sector $(25 \%)$, students (25\%), and with an average monthly income 500-1000 Jordanian Dinars. The prevalence of mild, moderate, and severe anxiety, according to BAI were $21.5 \%$ (95\% CI: 20.4 $22.7 \%$ ), $10.9 \%$ (95\% CI: 10.1-11.8\%), and 6\% (95\% CI: 5.4-6.7\%), respectively. BAI scores significantly differed according to age group, sex, marital status, and household income 


\begin{tabular}{|c|c|c|c|c|c|c|c|}
\hline Variable & $\begin{array}{l}\text { Total } \\
\text { n (\%) }\end{array}$ & $\begin{array}{l}\text { Mean BAI } \\
\text { score }\end{array}$ & $\begin{array}{c}\text { No anxiety } \\
n(\%)\end{array}$ & $\begin{array}{l}\text { Mild anxiety } \\
\text { n (\%) }\end{array}$ & $\begin{array}{c}\text { Moderate anxiety } \\
\text { n (\%) }\end{array}$ & $\begin{array}{c}\text { Severe anxiety } \\
n(\%)\end{array}$ & Pvalue \\
\hline $\begin{array}{c}\text { Age (years) } \\
18-24 \\
25-34 \\
35-44 \\
45-54 \\
55-64 \\
>65\end{array}$ & $\begin{array}{c}1509(28.6) \\
1375(26.1) \\
1159(22.0) \\
828(15.7) \\
321(6.1) \\
82(1.6)\end{array}$ & $\begin{array}{l}10.18 \\
8.90 \\
7.96 \\
5.71 \\
4.12 \\
3.31\end{array}$ & $\begin{array}{l}803(53.2) \\
779(56.7) \\
730(63.0) \\
602(72.7) \\
266(82.9) \\
68(82.9)\end{array}$ & $\begin{array}{c}349(23.1) \\
346(25.2) \\
244(21.1) \\
147(17.8) \\
42(13.1) \\
8(9.8)\end{array}$ & $\begin{array}{c}221(14.6) \\
157(11.4) \\
127(11.0) \\
57(6.9) \\
9(2.8) \\
3(3.7)\end{array}$ & $\begin{array}{c}136(9.0) \\
93(6.8) \\
58(5.0) \\
22(2.7) \\
4(1.2) \\
3(3.7)\end{array}$ & $<0.01$ \\
\hline $\begin{array}{l}\text { Sex } \\
\quad \text { Male } \\
\text { Female }\end{array}$ & $\begin{array}{l}2360(44.7) \\
2914(55.3)\end{array}$ & $\begin{array}{l}6.37 \\
9.67\end{array}$ & $\begin{array}{l}1659(70.3) \\
1589(54.5)\end{array}$ & $\begin{array}{l}423(17.9) \\
713(24.5)\end{array}$ & $\begin{array}{c}196(8.3) \\
378(13.0)\end{array}$ & $\begin{array}{c}82(3.5) \\
234(8.0)\end{array}$ & $<0.01$ \\
\hline $\begin{array}{l}\text { Smoking } \\
\text { Yes } \\
\text { No }\end{array}$ & $\begin{array}{c}1488(28.2) \\
3786(71.8)\end{array}$ & $\begin{array}{l}8.16 \\
8.12\end{array}$ & $\begin{array}{l}907(61.0) \\
2341(61.8)\end{array}$ & $\begin{array}{l}333(22.4) \\
803(21.2)\end{array}$ & $\begin{array}{l}154(10.3) \\
420(11.1)\end{array}$ & $\begin{array}{l}94(6.3) \\
222(5.9)\end{array}$ & 0.60 \\
\hline $\begin{array}{l}\text { Income * } \\
\quad<500 \\
501-1000 \\
1001-1500 \\
1501-2000 \\
>2000\end{array}$ & $\begin{array}{l}1467(27.8) \\
1777(33.7) \\
712(13.5) \\
446(8.5) \\
789(15.0)\end{array}$ & $\begin{array}{l}9.88 \\
8.19 \\
7.60 \\
7.16 \\
5.83\end{array}$ & $\begin{array}{l}769(52.4) \\
1093(61.5) \\
464(65.2) \\
286(64.1) \\
601(76.2)\end{array}$ & $\begin{array}{l}364(24.8) \\
392(22.1) \\
143(20.1) \\
105(23.5) \\
109(13.8)\end{array}$ & $\begin{array}{c}212(14.5) \\
188(10.6) \\
68(9.6) \\
41(9.2) \\
52(6.6)\end{array}$ & $\begin{array}{l}122(8.3) \\
104(5.9) \\
37(5.2) \\
14(3.1) \\
27(3.4)\end{array}$ & $<0.01$ \\
\hline $\begin{array}{l}\text { Number of } \\
\text { households } \\
0 \\
1 \\
2 \\
3 \\
4 \\
5 \\
=>6\end{array}$ & $\begin{array}{c}133(2.5) \\
332(6.3) \\
515(9.8) \\
775(14.7) \\
949(18.0) \\
1046(19.8) \\
1524(28.9)\end{array}$ & $\begin{array}{l}6.71 \\
8.42 \\
7.96 \\
7.19 \\
8.33 \\
8.32 \\
8.69\end{array}$ & $\begin{array}{l}87(65.4) \\
198(59.6) \\
335(65.0) \\
504(65.0) \\
589(62.1) \\
637(60.9) \\
898(58.9)\end{array}$ & $\begin{array}{c}31(23.3) \\
70(21.1) \\
106(20.6) \\
166(21.4) \\
187(19.7) \\
229(21.9) \\
347(22.8)\end{array}$ & $\begin{array}{c}9(6.8) \\
39(11.7) \\
39(7.6) \\
73(9.4) \\
118(12.4) \\
115(11.0) \\
181(11.9)\end{array}$ & $\begin{array}{l}6(4.5) \\
25(7.5) \\
35(6.8) \\
32(4.1) \\
55(5.8) \\
65(6.2) \\
98(6.4)\end{array}$ & 0.02 \\
\hline $\begin{array}{l}\text { Social Network** } \\
\quad 0 \\
1 \\
2 \\
3-4 \\
5-8 \\
=>9\end{array}$ & $\begin{array}{c}394(7.5) \\
664(12.2) \\
1144(21.7) \\
1749(33.2) \\
813(15.4) \\
530(10)\end{array}$ & $\begin{array}{l}12.67 \\
11.75 \\
8.57 \\
7.12 \\
6.46 \\
5.93\end{array}$ & $\begin{array}{l}154(39.1) \\
281(43.6) \\
670(58.6) \\
1180(67.5) \\
573(70.5) \\
390(73.6)\end{array}$ & $\begin{array}{l}124(31.5) \\
175(27.2) \\
273(23.9) \\
332(19.0) \\
153(18.8) \\
79(14.9)\end{array}$ & $\begin{array}{c}60(15.2) \\
116(18.0) \\
130(11.4) \\
164(9.4) \\
61(7.5) \\
43(8.1)\end{array}$ & $\begin{array}{l}56(14.2) \\
72(11.2) \\
71(6.2) \\
73(4.2) \\
26(3.2) \\
18(3.4)\end{array}$ & $<0.01$ \\
\hline $\begin{array}{l}\text { Social Support } \\
\quad 0 \\
1 \\
2 \\
3-4 \\
5-8 \\
=>9\end{array}$ & $\begin{array}{c}438(8.3) \\
700(13.3) \\
1141(21.6) \\
1484(28.1) \\
674(12.8) \\
837(15.9)\end{array}$ & $\begin{array}{c}14.81 \\
10.97 \\
8.98 \\
7.02 \\
5.91 \\
5.26\end{array}$ & $\begin{array}{l}158(36.1) \\
312(44.6) \\
645(56.5) \\
985(66.4) \\
514(76.3) \\
634(75.7)\end{array}$ & $\begin{array}{c}114(26.0) \\
203(29.0) \\
281(24.6) \\
311(21.0) \\
93(13.8) \\
134(16.0)\end{array}$ & $\begin{array}{c}72(16.4) \\
127(18.1) \\
146(12.8) \\
141(9.5) \\
40(5.9) \\
48(5.7)\end{array}$ & $\begin{array}{l}94(21.5) \\
58(8.3) \\
69(6.0) \\
47(3.2) \\
27(4.0) \\
21(2.5)\end{array}$ & $<0.01$ \\
\hline $\begin{array}{l}\text { Marital Status } \\
\text { Single } \\
\text { married } \\
\text { widowed } \\
\text { divorced }\end{array}$ & $\begin{array}{c}2248(42.6) \\
2823(53.7) \\
45(0.9) \\
149(2.8)\end{array}$ & $\begin{array}{l}9.37 \\
7.22 \\
6.44 \\
9.44\end{array}$ & $\begin{array}{c}1251(55.6) \\
1883(66.5) \\
32(71.1) \\
82(55.0)\end{array}$ & $\begin{array}{c}536(23.8) \\
555(19.6) \\
8(17.8) \\
37(24.8)\end{array}$ & $\begin{array}{c}291(12.9) \\
264(9.3) \\
4(8.9) \\
15(10.1)\end{array}$ & $\begin{array}{c}170(7.6) \\
130(4.6) \\
1(2.2) \\
15(10.1)\end{array}$ & $<0.01$ \\
\hline $\begin{array}{l}\text { Region of country } \\
\text { North } \\
\text { Center } \\
\text { South }\end{array}$ & $\begin{array}{c}1100(20.8) \\
3771(71.5) \\
403(7.6)\end{array}$ & $\begin{array}{l}8.56 \\
8.03 \\
8.96\end{array}$ & $\begin{array}{c}645(58.6) \\
2372(62.9) \\
222(55.1)\end{array}$ & $\begin{array}{l}263(23.9) \\
782(20.7) \\
100(24.8)\end{array}$ & $\begin{array}{c}122(11.1) \\
394(10.4) \\
58(14.4)\end{array}$ & $\begin{array}{c}70(6.3) \\
223(5.9) \\
23(5.7)\end{array}$ & 0.01 \\
\hline \multicolumn{8}{|l|}{ Work } \\
\hline $\begin{array}{l}\text { Public sector } \\
\text { Private sector }\end{array}$ & $\begin{array}{r}998(18.9) \\
1316(25.0)\end{array}$ & $\begin{array}{l}8.52 \\
8.44\end{array}$ & $\begin{array}{l}660(661 .) \\
845(64.2)\end{array}$ & $\begin{array}{l}210(21.0) \\
292(22.2)\end{array}$ & $\begin{array}{l}89(8.9) \\
116(8.8)\end{array}$ & $\begin{array}{l}39(3.9) \\
63(4.8)\end{array}$ & $\begin{array}{l}<0.01 \\
<0.01\end{array}$ \\
\hline Self-employment & $558(10.6)$ & 8.31 & $371(66.5)$ & $104(18.6)$ & $57(10.2)$ & $26(4.7)$ & 0.01 \\
\hline Student & $1306(24.8)$ & 7.67 & $716(54.8)$ & $306(23.4)$ & $182(13.9)$ & $102(7.8)$ & $<0.01$ \\
\hline
\end{tabular}

${ }^{*}$ Monthly income in Jordanian Dinar (JD); JD1 = US\$ 1.41

** How many close people do you have?

*** How many people do you have to talk with when you are under stress?

$(P<0.01)$. Moreover, having a more extensive social network, and having higher social support were significantly associated with lower anxiety scores $(P<0.01)$.

\section{Factors predicting anxiety}

Table 2 shows the results of the multivariable ordinal logistic regression analyses. Female gender $(\beta=0.41,95 \%$ 


\begin{tabular}{|c|c|c|c|}
\hline Variable & $\beta$ coefficient & $P$ value & 95\% Confidence Interval \\
\hline \multicolumn{4}{|l|}{ Sex } \\
\hline Male (Ref) & 0.47 & $<0.01$ & $0.34 \quad 0.59$ \\
\hline Female & -0.27 & $<0.01$ & $-0.33-0.20$ \\
\hline \multicolumn{4}{|l|}{ Marital status } \\
\hline \multicolumn{4}{|l|}{ Single (Ref) } \\
\hline Married & -0.07 & 0.94 & $-0.17 \quad 0.16$ \\
\hline Widowed & -0.43 & 0.23 & $-1.14 \quad 0.27$ \\
\hline Divorced & 0.2 & 0.27 & $-0.15 \quad 0.55$ \\
\hline \multicolumn{4}{|l|}{ Employed } \\
\hline Public employee & -0.05 & 0.057 & $-0.23 \quad 0.13$ \\
\hline Private employee & 0.08 & 0.36 & $\begin{array}{ll}-0.09 & 0.25\end{array}$ \\
\hline Self-employed & -0.01 & 0.92 & $-0.23 \quad 0.20$ \\
\hline Students & 0.13 & 0.23 & $\begin{array}{ll}-0.08 \quad 0.34\end{array}$ \\
\hline Unemployed & -0.14 & 0.28 & $-0.38 \quad 0.11$ \\
\hline \multicolumn{4}{|l|}{ Income $e^{*}$} \\
\hline \multicolumn{4}{|l|}{$<500$ (Ref) } \\
\hline $501-1000$ & -0.30 & $<0.01$ & $-0.44-0.16$ \\
\hline $1001-1500$ & -0.39 & $<0.01$ & $-0.58 \quad-0.19$ \\
\hline $1501-2000$ & -0.31 & $<0.01$ & $-0.54-0.09$ \\
\hline$>2000$ & -0.52 & $<0.01$ & $-0.71 \quad-0.33$ \\
\hline Number of households & 0.04 & 0.04 & $0.00 \quad 0.07$ \\
\hline Social network ${ }^{* *}$ & -0.17 & $<0.01$ & $-0.22-0.13$ \\
\hline Social support ${ }^{* * *}$ & -0.28 & $<0.01$ & $-0.32 \quad-0.23$ \\
\hline
\end{tabular}

${ }^{* *}$ Monthly income in Jordanian Dinar (JD); JD1 = US\$ 1.41

${ }^{* *}$ How many close people do you have?

${ }^{* * *}$ How many people do you have to talk with when you are under stress?

CI: 0.30-0.53, $P<0.01)$, followed by having more household members ( $\beta=0.04,95 \% \mathrm{CI}$ : $0.00-0.07, P=0.02$ ) were correlated with a higher degree of anxiety. Meanwhile, having a more extensive social network $(\beta=-0.18,95 \%$ CI: -0.22 to $-0.13, P<0.01)$, social support $(\beta=-0.28,95 \% \mathrm{CI}:-0.32$ to $-0.23, P<0.01)$, and older age groups $(\beta=-0.24,95 \% C I:-0.31$ to $-0.19, P<0.01$ ) were found to be negatively correlated with BAI scores. Higher income was also associated with lower BAI scores ( $\beta=-0.12,95 \% \mathrm{CI}$ : -0.16 to $-0.08, P<0.01$ ).

\section{Discussion}

In this sample of the Jordanian population, nearly four out of ten people were suffering from some degree of anxiety during home quarantine. Specifically, two out of ten participants had mild anxiety, while much less reported severe anxiety. Several sociodemographic factors were correlated with the degree of anxiety, including age, sex, marital status, income, number of households, and the strength of the social network.

Our study showed that $38.4 \%$ of the participants reported some degree of anxiety while quarantined. Although there are no large studies estimating the prevalence of anxiety in Jordan, multiple studies reported baseline anxiety rates to be $15-25 \%$, which is lower than our study (18-20). The prevalence of anxiety in our sample, as a measure of psychological distress, is in line with the rates detected in previous pandemics (9). Moreover, in a study conducted in China during this pandemic to measure the psychological distress in 52730 participants, the overall prevalence of psychological distress was $35 \%$
(21). The majority of Jordanians have never experienced pandemics with mass quarantine or lived under national defense laws (6). In times of pandemics, fears of the prolonged quarantine duration, catching the infection, and financial instability contribute significantly to the increased psychological distress (9). Therefore, developing a national plan to anticipate and tackle these concerns and barriers is of great importance.

Gender was the most robust factor associated with the level of psychological stress in our sample. The gender predilection to anxiety has been widely investigated in the literature (22). In a review article of 24 reports evaluating the psychological impact of quarantine in previous pandemics, it was found that females were more prone to psychological problems during pandemics and quarantine (9). Males and females have different coping mechanisms towards stressful conditions; females tend to believe they have no control over their worries. Therefore, they are prone to "worry about their worry", resulting in a vicious cycle of anxiety and inflating the psychological impact of stressful situations such as quarantine and pandemics (23). Furthermore, the implemented physical distancing policies obliged women to spend more time with their families at home; this has resulted in a significant recent increase in domestic violence, along with all other types of violence against women and girls (24). According to the United Nations Population Fund (UNPF), approximately 69\% pf Jordanian women and girls were victims of some sort of gender-based domestic violence during the COVID-19 crisis (25). Consequently, it is crucial that governments should increase resources to 
support shelters, hotlines and online counselling services to women having experienced domestic violence in order to have the ability to seek help when required. Moreover, the police and judiciary should deliver a strong and clear message that incidents of gender harassment would be given a high priority in law enforcement establishments.

There are several socioeconomic factors that mediate the relationship between gender and anxiety, of which the most essential is social support. Our study showed that the more extensive the social network a person has during quarantine, the lesser the degree of anxiety the person experiences. The influence of social support in reducing risks and improving outcomes (in terms of long- term morbidity and recurrence) for many psychiatric illnesses during stressful conditions is well described in the literature $(9,26)$. According to Brooks et al. (9), the loss of social support and interaction had drastic consequences on people under quarantine, as low social support was not only associated with higher anxiety levels, but also with higher long-term morbidity and recurrence rates. In Middle Eastern countries, including Jordan, family and friends provide a refuge from life stressors and support in states of poor health, with more emphasis put on family bonds, clan traditions and religious rituals $(26,27)$. Thus, people in quarantine should be advised to keep in touch with their loved ones, not necessarily through face-to-face interaction, but also through social media platforms. Moreover, due to their important roles in Middle Eastern countries, social and religious leaders should be involved in informing people during the pandemic.

Age was also correlated with stress during quarantine, with older persons having markedly lower BAI scores. This association has been well documented in the literature (21,28). However, Qiu, et al. (10) found that older people are more prone to psychological distress during the COVID-19 pandemic. The nature of society could explains this discrepancy in the Middle East, where older people have more extensive social support compared to other cultures (27). Older persons are less prone to psychological problems, in general, because they tend to be more emotionally and financially stable, as well as having a more respected societal role (29). In addition, they appear to be more resilient towards health-related distress, having greater awareness of developing physical illnesses with age (30). This finding, however, should be interpreted cautiously, as this apparent variation could be due to the "cohort effect" of cross-sectional studies; younger generations have been exposed to different life stressors than older generations for different periods, and a causal relationship cannot be concluded from cross-sectional studies.

The financial burden of the quarantine also plays a crucial role in modifying response to quarantine. Those who had lower incomes and a higher number of household members appeared to experience higher levels of anxiety. According to Brooks et al. (9) people with lower combined household income suffered from higher levels of post-traumatic stress and anger. This adverse effect of income insecurity is not only associated with poor psychological outcomes but also one of the most commonly recognized barriers to adherence to home quarantine (31). This observation warrants action to give financial support for people at risk, lowering the odds of intolerable anxiety and consequently greater adherence to home quarantine.

In response to the developing changes resulting from the impact of the emergence of the COVID-19 pandemic, and the challenges it poses to both the national and global economy, the Jordanian government has also approached the crisis by establishing a national account for donation funds (Himmet Watan), and so far has collected more than US\$ 130 million from donors and enterprises to help Jordanians directly affected by COVID-19, especially day labourers who have lost their main source of livelihood (32). Furthermore, the Central Bank of Jordan injected additional liquidity to banks (US\$ 775 million) in order to help maintain interest rate stability in order to support the private sector (33). The Central Bank also updated procedures and guidelines to allow postponement of loan repayments without negative credit rating. In addition, social security measures were put in place to support those losing employment (34).

\section{Limitations}

Utilizing convenience sampling and social media for data collection may not give an accurate picture of all groups in the community; however, it is the safest and most efficient way to reach the population during home quarantine. The nature of the cross-sectional study cannot draw a causal relationship, but only generates a hypothesis of possible association. The timing of the questionnaire distribution in the early days of quarantine might not measure actual quarantine-related stress. Nevertheless, our study provided baseline data for stress during home quarantine, and if taken into consideration earlier in the quarantine, a significant level of psychological stress could be prevented.

\section{Conclusion}

Our study showed that about $40 \%$ of the participants experienced some degree of quarantine-related anxiety. Being female, older age, lack of social support, and limited financial support were significantly correlated with higher degrees of quarantine-related anxiety. Our results provide policy-makers with data to take action to mitigate these factors. Furthermore, vulnerable groups should be offered psychological support in terms of online counseling and support groups. Future research should focus on individual fears and barriers in order to draw more precise recommendations and guidelines, taking into account the religious and cultural context.

Funding: None.

Competing interests: None declared. 


\section{L'impact de la crise de la COVID-19 sur la santé mentale : l'anxiété liée au début de la quarantaine et ses corrélats chez les Jordaniens}

\section{Résumé}

Contexte : La Jordanie a mis en place un confinement national et a recommandé l'auto-quarantaine en réponse à la pandémie de COVID-19. De telles mesures devraient avoir des conséquences sur la santé mentale.

Objectifs : La présente étude avait pour objectif d'estimer la prévalence de l'anxiété liée à la quarantaine et ses corrélats socio-économiques.

Méthodes : En mars 2020, un questionnaire en ligne a été utilisé pour recueillir des informations sur l'anxiété et les facteurs liés à la quarantaine dans un échantillon non représentatif de la population jordanienne. L'inventaire de Beck pour l'anxiété a été utilisé pour évaluer le niveau de stress. À l'aide du logiciel STATA 16, une régression logistique ordinale multivariable a été effectuée pour estimer le coefficient bêta ( $\beta$ ) et l'intervalle de confiance (IC) à $95 \%$ correspondant du niveau d'anxiété.

Résultats : En tout, 5274 participants ont répondu à l'enquête. La prévalence de l'anxiété légère, modérée et sévère était respectivement de $21,5 \%, 10,9 \%$ et $6 \%$. Le sexe féminin $(\beta=0,47$, IC $95 \%: 0,34$ à 0,59$)$ et un plus grand nombre de membres du foyer ( $\beta=0,04$, IC $95 \%$ : 0,00 à 0,07) étaient corrélés avec un degré d'anxiété plus élevé, tandis que l'âge plus avancé $(\beta=-0,27$, IC $95 \%$ : $-0,33$ à $-0,20)$, le fait d'avoir un réseau social plus étendu $(\beta=-0,17$, IC 95\% : $-0,22$ à $-0,13)$, le soutien social ( $\beta=-0,28$, IC $95 \%$ : -0,32 à -0,23) et un revenu plus élevé (plus de 2000 dinars jordaniens par rapport à la référence, $\beta=-0,52$, IC $95 \%$ : -0,71 à -0,33) étaient corrélés avec des scores de l'inventaire de Beck plus faibles.

Conclusions : Nos résultats ont montré que près de quatre participants sur dix souffraient d'anxiété liée à la quarantaine. Les jeunes participants, les femmes et les personnes ayant un faible soutien social étaient plus susceptibles de connaître une anxiété liée à la quarantaine. Ces résultats soulignent l'importance de cibler ces groupes pour atténuer les conséquences de la quarantaine à domicile sur la santé publique.

$$
\begin{aligned}
& \text { أثر أزمة كوفيد-19 على الصحة النفسية: القلق المبكر المرتبط بالحجر الصحي وعو امل ارتباطه بين الأردنيين }
\end{aligned}
$$

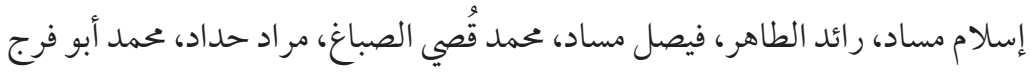

لهذه التدابية طبق عو الأردن حظر الخروج على الحلى الصعيد الوطني، وأوصى بتنفيذ الحجر الصحي الذاتي استجابةً لجائحة كوفيد-19 ـ ومن المتوقع أن يكون الأهداف: في هذه الدراسة، تمثل هدفنا في تقدير مدى انتشار القلق المرتبط بالحجر الصحي وعوامل ارتباطه الاجتماعية والاقتصادية. طرق البحث: استُخدم استبيان إلكتروني لجمع معلومات حول القلق المرتبط بالحجر الصحي والعوامل ذات ذات الصلة من عينة غير تمثيلية للسكان

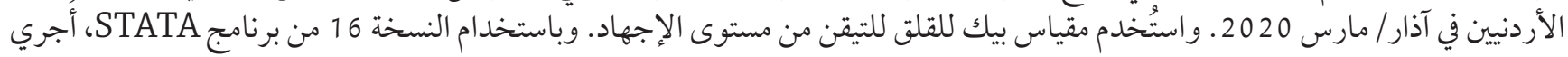

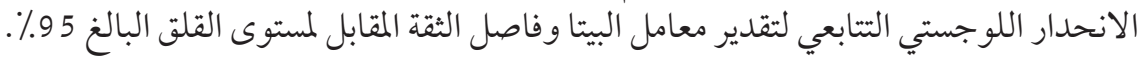

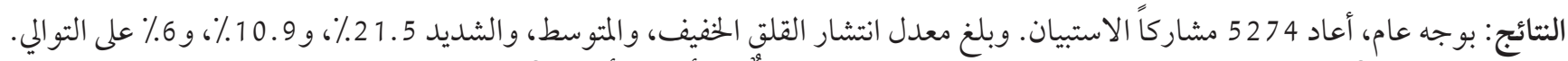

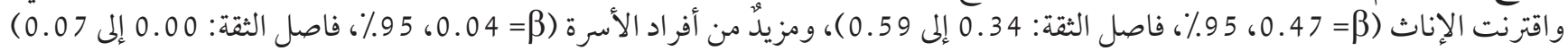

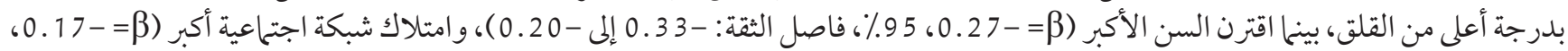

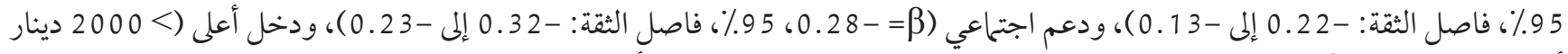
أردني مقابل المرجع،

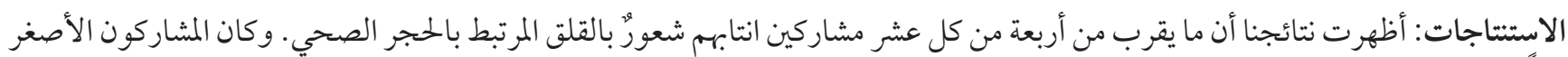

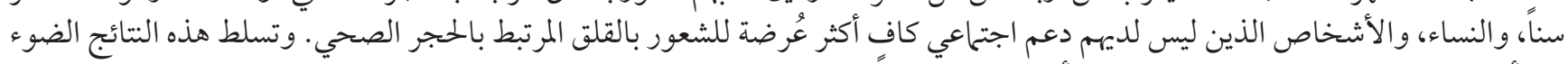

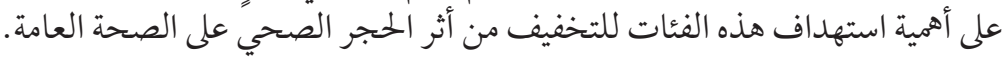




\section{References}

1. Guo Y-R, Cao Q-D, Hong Z-S, Tan Y-Y, Chen S-D, Jin H-J, et al. The origin, transmission and clinical therapies on coronavirus disease 2019 (COVID-19) outbreak - an update on the status. Mil Med Res. 2020;7(1):11.

2. World Health Organization. WHO COVID-19 Dashboard [Internet].

3. Lu H. Drug treatment options for the 2019-new coronavirus (2019-nCoV). Biosci Trends. 2020 Feb;14(1):69-71.

4. Guan W, Ni Z, Hu Y, Liang W, Ou C, He J, et al. Clinical characteristics of 2019 novel coronavirus infection in China. N Engl J Med. 2020 Feb;2020.02.06.20020974.

5. Reality Check Team. Coronavirus: What measures are countries taking to stop it? - BBC News [Internet]. 2020 (https://www.bbc. com/news/world-51737226).

6. Jordan's efforts to contain COVID-19: A careful interpretation of the encouraging numbers | Jordan Times [Internet]. (http:// www.jordantimes.com/opinion/mohammad-majed-abufaraj/jordans-efforts-contain-covid-19-careful-interpretation-encouraging).

7. Van Bortel T, Basnayake A, Wurie F, Jambai M, Koroma AS, Muana AT, et al. Psychosocial effects of an Ebola outbreak at individual, community and international levels. Bull World Health Organ [Internet]. 2016 Mar 1;94(3):210-4.

8. Rubin GJ, Potts HWW, Michie S. The impact of communications about swine flu (influenza A HINIv) on public responses to the outbreak: Results from 36 national telephone surveys in the UK. Health Technol Assess (Rockv) [Internet]. 2010 Aug 7];14(34):183-266.

9. Brooks SK, Webster RK, Smith LE, Woodland L, Wessely S, Greenberg N, et al. Rapid Review The psychological impact of quarantine and how to reduce it: rapid review of the evidence. The Lancet. 2020;395(10227):912-920.

10. Hawryluck L, Gold WL, Robinson S, Pogorski S, Galea S, Styra R. SARS control and psychological effects of quarantine, Toronto, Canada. Emerg Infect Dis. 2004;10(7):1206-12.

11. The World Bank. Data for Jordan [Internet]. 2019 (https://www.worldbank.org/en/country/jordan).

12. Family and Population Surveys Directorate Department of Population and Social Statistics. Estimated population of the Kingdom by municipality and sex, at end-year 2019 [Internet]. (http://dosweb.dos.gov.jo/DataBank/Population_Estimares/Municipalities2019.pdf).

13. Jordanian Department of Statistics. Jordan statistical yearbook [Internet]. 2017 (http://dosweb.dos.gov.jo/databank/Yearbook2017/YearBook2017.pdf).

14. Miniwatts Marketing Group. Jordan internet stats and telecommunications report 2018 (https://www.internetworldstats.com/ me/jo.htm).

15. Fydrich T, Dowdall D, Chambless DL. Reliability and validity of the beck anxiety inventory. J Anxiety Disord. 1992;6(1):55-61.

16. Rector NA, Arnold PD. Assessment of patients with anxiety disorders. In: Psychiatric Clinical Skills. Mosby Inc.; 2006:71-89.

17. Al-Shatti ST. Psychometric properties of the Arabic Version of the Beck Anxiety Inventory in the State of Kuwait. Journal of Educational and Psychological Sciences. 2015;16(2) (https://journal.uob.edu.bh/handle/123456789/2597).

18. Al-Rawashdeh BM, Saleh MYN, Mustafa RB, Alkhoujah MF, Elkhatib AH, Alsghaireen H, et al. Prevalence of depression and anxiety among otolaryngology outpatients at Jordan University Hospital. Perspect Psychiatr Care. 2019 Jul 1;55(3):383-95.

19. Dalky HF, Gharaibeh A. Depression, anxiety, and stress among college students in Jordan and their need for mental health services. Nurs Forum [Internet]. 2019 Apr 16;54(2):205-12. (https://onlinelibrary.wiley.com/doi/abs/10.1111/nuf.12316).

20. Alslman ET, Baker NA, Dalky H. Mood and anxiety disorders among adolescent students in Jordan. East Mediterr Health J. 2017 Sep 1;23(9):604-10. https://doi.org/10.26719/2017.23.9.604

21. Qiu J, Shen B, Zhao M, Wang Z, Xie B, Xu Y. A nationwide survey of psychological distress among Chinese people in the COVID-19 epidemic: implications and policy recommendations. Gen Psychiatry. 2020 Mar 6;33(2):e100213. (http://gpsych.bmj.com/ lookup/doi/10.1136/gpsych-2020-100213)

22. Reisner SL, Katz-Wise SL, Gordon AR, Corliss HL, Austin SB. Social epidemiology of depression and anxiety by gender identity HHS Public Access. J Adolesc Heal. 2016;59(2):203-8.

23. Bahrami F, Yousefi N. Females are more anxious than males: a metacognitive perspective. Iran J Psychiatry Behav Sci. 2011;5(2):83-90.

24. United Nations Entity for Gender Equality and the Empowerment of Women. Impact of COVID-19 on violence against women and girls and service provision: UN Women rapid assessment and findings. Geneva: UN Women; 2020 (https://www.unwomen. org/en/digital-library/publications/2020/05/impact-of-covid-19-on-violence-against-women-and-girls-and-service-provision).

25. Anderson K. Daring to ask, listen, and act: a snapshot of the impacts of COVID-19 on women and girls' rights and sexual and reproductive health. Geneva: UNFPA; 2020 (https://reliefweb.int/report/jordan/daring-ask-listen-and-act-snapshot-impacts-covid-19-women-and-girls-rights-and-sexual).

26. Hasan AA-H, Musleh M. Public stigma toward mental illness in Jordan: a cross-sectional survey of family members of individuals with schizophrenia, depression, and anxiety. J Psychosoc Nurs Ment Health Serv. 2017 Jun 1;55(6):36-43. (http://www.healio. com/doiresolver?doi=10.3928/02793695-20170519-05). 
27. Nydell MK. Understanding Arabs: a contemporary guide to Arab society. Intercultural Press:311

28. Roberts T, Esponda GM, Krupchanka D, Shidhaye R, Patel V, Rathod S. Factors associated with health service utilisation for common mental disorders: a systematic review. BMC Psychiatry. 2018 Aug 22;18(1):262. doi: 10.1186/s12888-018-1837-1.

29. Verstaen A, Haase CM, Lwi SJ, Levenson RW. Age-related changes in emotional behavior: evidence from a 13-year longitudinal study of long-term married couples. Emotion. 2018;20(2).

30. Kessler RC, Birnbaum H, Bromet E, Hwang I, Sampson N, Shahly V. Age differences in major depression: Results from the national comorbidity survey replication (NCS-R). Psychol Med. 2010;40(2):225-37.

31. Gershon RR, Zhi Q, Chin AF, Nwankwo EM, Gargano LM. Adherence to emergency public health measures for bioevents: review of US studies. Disaster Med Public Health Prep. 2018;12(4):528-35.

32. Al Bawaba news. Jordan's National Fund Collected \$131.1 million since its launch (https://www.albawaba.com/news/jordan's-national-fund-collected-1311-million-its-launch-13593360.

33. Central Bank Of Jordan. The Central Bank of Jordan announces a set of procedures aimed to contain the repercussions of the emerging Corona virus impact on the national economy (https://www.cbj.gov.jo/DetailsPage/CBJEn/NewsDetails.aspx?ID=279).

34. KPMG Global. Jordan - Measures in response to COVID-19 (https://home.kpmg/xx/en/home/insights/2020/04/jordan-government-and-institution-measures-in-response-to-covid.html). 